\title{
Savings Wedge, Productivity Growth, and Intemational Capital Flows
}

\author{
Ly Dai Hung ${ }^{1,2+}$ \\ ${ }^{1}$ Vietnam Central Economic Commission, Hanoi, Vietnam \\ ${ }^{2}$ Thang Long Institute of Mathematics and Applied Sciences (TIMAS), Hanoi, Vietnam
}

\begin{abstract}
The empirical evidence derived from an analysis of a panel sample of 162 economies for the 1980-2013 period demonstrates that a higher productivity growth rate is associated with greater savings. The savings wedge, a type of financial friction, underlies this correlation. The growth rate has a positive influence on investment. Since net capital inflows represent a gap between domestic investment and savings, their fluctuation over time is driven by the dynamics of productivity growth. The evidence also implies that the neoclassical growth model works on the investment side while the allocation puzzle still applies on the savings side of the net capital inflows equation.
\end{abstract}

Keywords: International Capital Flows, Financial Friction, Productivity Growth, Savings Wedge

JEL Classifications: H20, F21, F41

Received 29 November 2019, Revised 19 March 2020, Accepted 27 April 2020

\section{Introduction}

There are two stylized facts regarding the dynamics of international capital flows between countries, as illustrated in Figure 1.

Fact 1: Net capital inflows fluctuate over time in both advanced and emerging economies. In Panel A, for advanced economies over the 1980-1986 period, capital inflows increase but decrease over the 1986-1997 period, and then increase continuously until they finally peak in 2006 at $1.8 \%$. For emerging economies, net capital inflows also experience high fluctuation along their downward trend to a bottom of $-4.2 \%$ in 2006 , before climbing to $0 \%$.

Fact 2: Net capital inflows are highly (positively or negatively) correlated with productivity growth over time. In Panel B, for advanced economies over the 1986-1991 period, capital inflows decrease from $0.45 \%$ to $0 \%$ while the growth rate also declines from $0.28 \%$ to $-0.6 \%$. Over the 1992-2005 period, the expansion of capital inflows is accompanied by a surge of growth, except for a dip in growth in 2000. In Panel C, for emerging economies between 1986 and 1990 , capital inflows decrease from $1.9 \%$ to $0.06 \%$ while the growth rate decelerates from $0.59 \%$ to $-0.3 \%$. Over the $1999-2006$ period, however, the decline in capital inflows accompanies 
an escalation in productivity growth. This observed pattern of capital inflows poses a challenge for past studies (see Gourinchas \& Rey, 2014 for a recent survey). One line of the existing research (Lucas, 1990; Matsuyama, 2004) based on the neoclassical growth model usually emphasizes the long-run value of net capital inflows. Thus, it can only explain whether an economy tends to experience an inflow or outflow of capital but not the fluctuation of net capital inflows over time (Fact 1). Other papers on the uphill capital flows literature (Prasad, Rajan, \& Subramanian, 2007; Alfaro, Kalemli-Ozcan, \& Volosovych, 2014) usually employ a cross-sectional data sample to compare patterns in capital flows between countries. Therefore, they do not capture the dependence of capital flows on productivity growth over time (Fact 2). Our paper aims to fill this research gap.

Figure 1. Patterns of international capital flows over time.

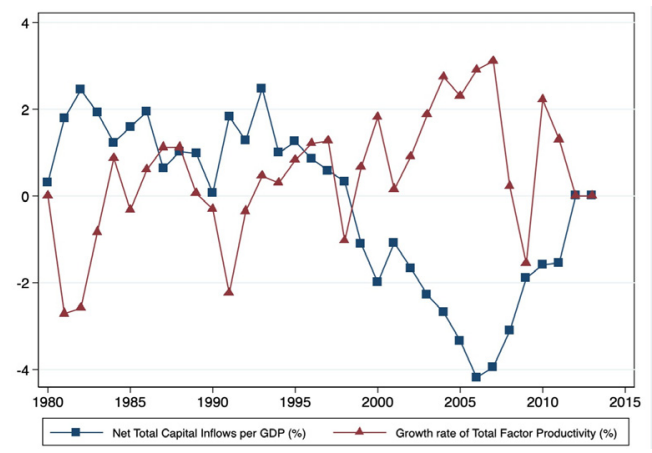

(A) Net Total Capital Inflows in Advanced Economies and in Emerging and Developing Economies

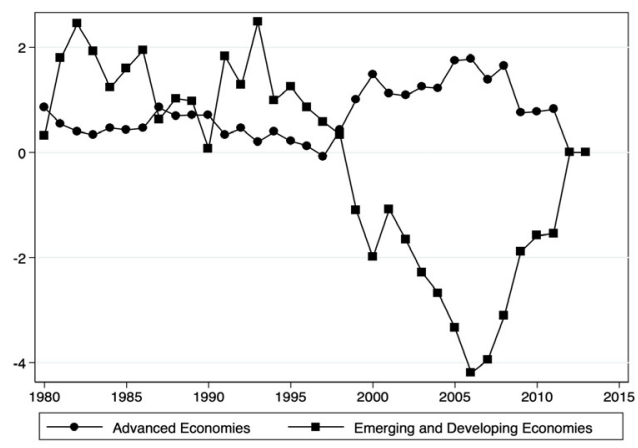

(B) Capital Flows and Productivity Growth in Advanced Economies

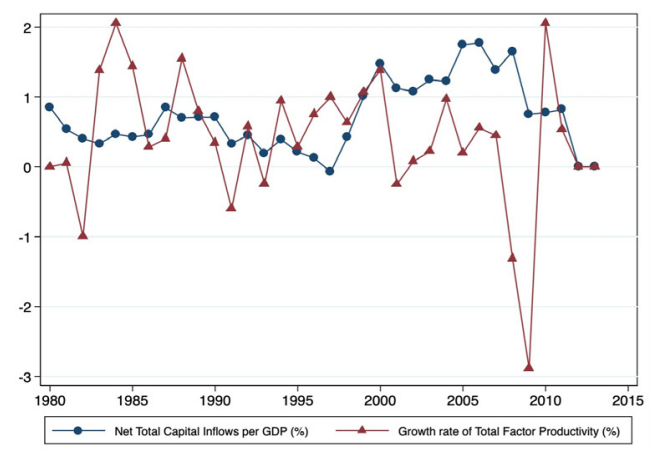

(C) Capital Flows and Productivity Growth in Emerging and Developing Economies

(Note) Each variable is a weighted average of all the countries in a group (i.e., advanced and emerging economies). A country's weight is equal to its gross domestic product (GDP) divided by its group's total GDP. Country classifications follow the work of Mendoza and Terrones (2012).

We demonstrate that these two stylized facts can be jointly explained by the existence of the savings wedge, a type of financial friction that differentiates the rate of return on household 
savings from the lending interest rate. Specifically, productivity growth can both increase investment and accelerate savings. When investment increases less than savings, the increase in productivity growth is associated with a reduction in net capital inflows, which is equal to the gap between domestic investment and savings. Otherwise, the escalation of growth is associated with the stimulation of capital inflows. Thus, the dependence of capital flows on productivity growth (Fact 2) is explained by the existence of the savings wedge. Moreover, since productivity growth fluctuates over time, net capital inflows also change over time (Fact 1). In brief, the dynamic pattern of international capital flows is dependent on the savings wedge.

The paper belongs to the stream of the literature on cross-border capital flows. Lucas (1990) analyzed one small, open economy to investigate why capital does not flow to emerging economies, which are characterized by capital scarcity and a high marginal product of capital. The author, however, focuses on the value of net capital inflows and does not address their dependence on productivity growth. Gourinchas and Jeanne (2013) established the existence of the allocation puzzle using a data sample of emerging economies: one country growing faster tends to receive less capital inflows. Recently, Alfaro, Kalemli-Ozcan, and Volosovych (2014) employed a cross-sectional sample of both advanced and emerging economies to demonstrate that net capital inflows increase productivity growth. The common shortcoming of these papers is that the cross-sectional data do not account for the fluctuation in international capital flows over time.

Our paper complements the main results of the aforementioned papers. First, we emphasize the role of financial friction in shaping the pattern of capital flows. With the existence of friction, productivity growth can influence both savings and investment. Thus, changes in the growth rate are translated into fluctuations in net capital inflows over time. Second, we capture the dynamics of capital flows using a panel data sample of 160 advanced and emerging economies. We then demonstrate that the neoclassical growth model explains the investment side while the allocation puzzle relies on the savings side of net capital inflows.

The paper also sheds new light on the high correlation between savings and growth. Carroll, Overland, and Weil (2000) pointed out the fact that, since consumers postpone current consumption in response to a rising interest rate, higher growth leads to greater savings. Their closed-economy model, however, isolates the crucial role of savings from its interaction with the international capital market. Bernanke (2005) showed that a high level of savings by emerging economies underlies the flow of capital from emerging to advanced economies. In an open, multi-country economy, Coeurdacier, Guibaud, and Jin (2015) demonstrated that credit constraint combined with demographic changes explains the high savings rate in emerging economies. Thus, an emerging economy with severe credit constraint can have both a high savings rate and a high growth rate. The correlation between savings and growth in financial integration is also characterized by Song, Storesletten, and Zilibotti (2011). For an open, 
transitional economy, the movement of labor from low-productivity to high-productivity sectors increases both productivity growth and savings by boosting household income.

Our paper differs from previous papers by revealing the mechanism by which productivity growth directly affects savings in the context of financial integration. An improvement in the growth rate is associated with a higher savings wedge, which, in turn, can result in greater savings. Thus, an increase in productivity growth accompanies greater savings. With integration, if savings increases more than investment, the higher productivity growth rate can lead to the outflow of capital.

This paper is organized as follows. After this introduction, Section 2 presents the theoretical framework, including the data and model. Section 3 provides empirical evidence on the pattern of international capital flows. Finally, Section 4 concludes.

\section{Framework}

\section{A. Data}

The dataset is a panel sample including 162 economies for the period between 1980 and 2013. The dependent variable is net capital inflows. The independent variables include the savings wedge and the productivity growth rate.

International capital flows are measured by the negative value of the annual current account divided by GDP, denoted by negCA2y, divided by the total population, denoted by negCApc. The former is a percentage and the latter is based on current national prices in United States dollars (USD). Scaling output or population eliminates the country-size effect on the measurement of net capital inflows. These two variables are extracted from the updated and extended version of the dataset of net private and public capital flows constructed by Alfaro, Kalemli-Ozcan, and Volosovych (2014). This dataset is a panel sample of international capital flows covering a wide range of countries including both emerging and advanced economies for the time period between 1980 and 2013 .

We also decomposed net capital inflows into its constituent components-savings and investment. According to the international macroeconomics theory (Obstfeld \& Rogoff, 1996), net capital inflows are equal to the gap between domestic investment and savings. Savings can be measured in two different ways. The first is the ratio of gross savings to GDP ( $S 2 y)$. The second is per capita gross savings in USD $(S p c)$, which is obtained by dividing gross savings in current USD by the total population. These different measures for savings are used to check the robustness of the empirical model. Furthermore, investment is the ratio of gross capital formation to GDP $(I 2 y)$. The savings-to-GDP ratio, the investment-to-GDP ratio, and 
gross savings are explored using World Development Indicators. The total population was drawn from the Pen World Table (PWT) 8.1 (2015).

The savings wedge, denoted by $\left(W e d g e^{j}\right)$, was defined by Gourinchas and Jeanne (2013) as the difference between the domestic interest rate $\left(R^{j}\right)$ and the world interest rate $\left(R^{w}\right)$ for economy $j$, as follows:

$$
R^{j}=\left(1-W e d g e^{j}\right) R^{w}
$$

We employed a different strategy than Gourinchas and Jeanne (2013), who calibrated the wedge such that the pattern of net capital inflows predicted by the theoretical model fit the cross-sectional data sample of emerging economies. We, however, compute the savings wedge directly from the data and use it as an independent variable to explain the pattern of international capital flows. In short, we used an empirical savings wedge, which differs from the theoretical savings wedge used in the past literature.

The savings wedge is a type of financial friction that creates a gap between the rental of capital for domestic firms (which is equal to the world interest rate for one small, open economy, modeled on the work of Gourinchas \& Jeanne, 2013) and the rate of return on savings for households. Since a common world rental rate of capital across countries does not exist, we cannot compute the exact measure of the savings wedge using data alone. However, we can observe the deposit interest rate, $R^{d, j}$, which is equal to the rate of return on savings, and the lending interest rate, $R^{l, j}$, which is equal to the rental rate of capital in country $j$ at time $t$. Both the deposit and lending rates are sourced from the World Development Indicators. We then computed the savings wedge as a percentage using the following equation:

$$
\operatorname{Wedge}_{t}^{j}=\frac{R_{t}^{l, j}-R_{t}^{d, j}}{R_{t}^{l, j}} .100
$$

The productivity growth rate as a percentage, denoted by TFPgrowth, is computed using the total factor productivity level (TFP) in constant 2005 USD, which was also sourced from the PWT 8.1 (2015). In this updated version, the productivity level was computed using three novel methods. First, the share of factor income is different between countries and time. Second, physical capital stock was decomposed into different types of assets, each of which has a specific depreciation rate. Then, they were combined with the human capital index, which accounts for the average years of schooling, to yield TFP. Third, the production function employed in PWT 8.1 is the Harrod-neutral production function with labor-augmenting technology.

Moreover, we also used two other measures for productivity growth. The first was output growth rate per capita as a percentage, denoted by GDPpcgrowth. According to the literature 
on economic growth (Solow, 1956; Swan, 1956), at long-run equilibrium, the growth rate of output per capita is determined by the growth rate of productivity. Recently, Alfaro, KalemliOzcan, and Volosovych (2014) used the output growth rate per capita, instead of the TFP growth rate, to explain the pattern of capital flows between countries. The second measure is the growth rate of output as a percentage, denoted by GDPgrowth, which is equal to the sum of the growth rate of output per capita and the growth rate of the population. Thus, it also illustrates the productivity growth rate. In terms of data, output is the real GDP in constant national 2005 prices in USD. Output per capita is attained by dividing output by the total population. Both the output and population data were drawn from the PWT 8.1.

Table 1. Descriptive Statistics

\begin{tabular}{lccccc}
\hline \multicolumn{1}{c}{ Variable } & Obs & Mean & Std. Dev. & Min & Max \\
\hline Net Total Capital Inflows per GDP (\%) (negCA2y) & 4973 & 3.751759 & 13.55661 & -304.0221 & 240.4958 \\
Net Total Capital Inflows per capita (USD) (negCApc) & 5100 & -91.29572 & 1661.487 & -28141.84 & 16484.09 \\
Gross Savings per GDP (\%) (S2y) & 4697 & 20.05024 & 15.76129 & -233.9462 & 342.1523 \\
Gross Savings per capita (USD) (Spc) & 3561 & 2986.797 & 4890.275 & -49873.13 & 73938.26 \\
Gross Capital Formation per GDP (\%) (I2y) & 5382 & 23.57126 & 10.80658 & -2.424358 & 219.0694 \\
Savings Wedge (\%) (Wedge) & 4195 & 48.08914 & 22.10123 & -68.43333 & 99.8000 \\
Productivity Growth Rate (\%) (TFPgrowth) & 3259 & 0.105378 & 5.34612 & -66.07364 & 52.59184 \\
Output per capita Growth Rate (\%) (GDPpcgrowth) & 4772 & 1.46388 & 6.60297 & -69.22271 & 91.79552 \\
Output Growth Rate (\%) (GDPgrowth) & 4875 & 3.57206 & 6.61251 & -66.11992 & 106.2798 \\
\hline
\end{tabular}

Table 1 provides summary statistics on the panel sample. The net capital inflows-to-output ratio has a mean of $3.75 \%$ with a standard deviation of $13.5 \%$. Compared to net capital inflows, both the savings ( $S 2 y)$ and investment rates (I2y) have a higher mean and a greater standard deviation. Net capital inflows per capita exhibits a mean of -91 USD with a standard deviation of 1,661 USD. Savings per capita has a higher mean of 2,986 USD and a higher standard deviation of 4,890 USD than capital inflows per capita. Finally, the savings wedge has a mean of $48 \%$ with a $22 \%$ standard deviation. Similarly, the productivity growth rate exhibits quite a large standard deviation, with a mean of $0.1 \%$ and a standard deviation of $5.3 \%$. In comparison with productivity growth, the growth rate of output per capita has a higher mean at $1.46 \%$ and standard deviation at $6.60 \%$. The output growth rate has the highest mean at $3.57 \%$ with the largest standard deviation at $6.61 \%$. Therefore, the dataset offers rich variation for exploring the relationship between productivity growth and net capital inflows.

\section{B. Model}

The construction of the empirical model is based on the recent cross-border capital flows 
literature. In the neoclassical growth model (Solow, 1956), a higher productivity growth rate reduces the long-run capital accumulation level, which, in turn, increases the marginal product of capital. With international financial integration, capital flows from economies with a low marginal product of capital to economies with a high marginal product of capital. Thus, an economy with a higher productivity growth rate receives more capital inflows. Prasad, Rajan, and Subramanian (2007), however, recorded evidence on the existence of an uphill pattern of capital flows wherein capital flows from emerging economies with a high growth rate to advanced economies with a low growth rate. Thus, economies with a high growth rate receive less capital inflows. Recent papers have incorporated financial friction into their models to explain the uphill capital flows pattern. Coeurdacier, Guibaud, and Jin (2015) used the borrowing constraint imposed on young people; Sandri (2014) employed the credit constraint in an incomplete financial market; and Song, Storesletten, and Zilibotti (2011) used firms' limited access to credit markets. In brief, the literature suggests that a combination of economic growth and financial friction explain the pattern of international capital flows.

We employed a fixed-effects panel method to analyze net capital inflows. The regression controlled for both country fixed-effects and time fixed-effects. Specifically, the error term $u^{j}$ is assumed to vary non-stochastically across economy $j$ and over time $t$. Using this methodology, the regression focuses on the mechanism underlying capital flow patterns, controlling for the unobserved country and time factors. We use the following empirical models:

$$
\begin{aligned}
& \text { negCA2 } y_{t}^{j}=\propto+\beta^{1} . \text { TFPgrowt } h_{t}^{j}+u_{t}^{j} \\
& n e g C A 2 y_{t}^{j}=\propto+\beta^{2} . \text { Wedge }_{t}^{j}+u_{t}^{j} \\
& \text { Wedge }_{t}^{j}=\propto+\beta^{1} . \text { TFProwt }_{t}^{j}+u_{t}^{j}
\end{aligned}
$$

Model (1) examines the dependence pattern of net capital inflows on productivity growth. The neoclassical growth theory (Solow, 1956) predicts that a higher growth rate increases net capital inflows. Thus, the coefficient $\beta^{1}$ is expected to be positive: $\beta^{1}>0$. But according to the uphill pattern of capital flows posited by Prasad, Rajan, and Subramanian (2007), the coefficient $\beta^{1}$ is also expected to be negative: $\beta^{1}<0$. Thus, the sign of $\beta^{1}$ is undetermined.

Model (2) investigates the dependence pattern of net capital inflows on the savings wedge. Gourinchas and Jeanne (2013) demonstrated that a higher savings wedge is associated with greater savings, which reduces net capital inflows. Thus, the coefficient $\beta^{2}$, which measures the impact of the savings wedge on net capital inflows, is expected to be negative: $\beta^{2}<0$.

We also employed an additional model, as implied by Equation (3), to emphasize the role of the savings wedge. The coefficient $\beta^{3}$ illustrates the impact of productivity growth on the savings wedge. Its expected value can be either positive or negative. For a positive value, 
$\beta^{3}>0$, a higher growth rate is associated with a larger wedge.

Our core model is specified as the following:

$$
\text { negCA2y } y_{t}^{j}=\propto+\beta^{\text {growth }} . \text { TFPgrowth } t_{t}^{j}+\beta^{\text {wedge }} . \text { Wedge } e_{t}^{j}+u_{t}^{j}
$$

The core model is convenient for exploring the pattern of international capital flows. First, the model differentiates between the impact of productivity growth and that of financial friction on net capital inflows. The coefficient $\beta^{g r^{0} \text { wth }}$ measures the impact of economic growth while $\beta^{\text {wedge }}$ measures the impact of the savings wedge on net capital inflows. Second, the model evaluates the relative importance of each variable in shaping the pattern of capital flows. Recently, Alfaro, Kalemli-Ozcan, and Volosovych (2008) added institutional quality into a regression of net capital inflows on per capita income. This addition caused the coefficient of per capita income to become insignificant. The authors then concluded that institutional quality accounts for the dependence of net capital inflows on per capita income. Using the same strategy, if the coefficient of economic growth becomes insignificant when the savings wedge is added to the regression of net capital inflows on productivity growth, the evidence proves that the savings wedge can account for capital inflows' dependence on economic growth.

We also changed the variables in the regression models. Net capital inflows were decomposed into savings and investment while the productivity growth rate was alternatively measured using per capita GDP growth rate and GDP growth rate.

\section{Evidence}

We first examined the dependence of capital flows on productivity growth. Then, we investigated the role of the savings wedge in shaping the pattern of international capital inflows. Finally, we conducted robustness checks on the regression results.

\section{A. Pattem of intemational capital flows}

Table 2 reports the regression of net capital inflows and their components on the productivity growth rate. The common result is that the growth rate has a negative impact on net capital inflows. In Column 1, a $1 \%$ increase in the TFP growth rate is associated with a $0.226 \%$ reduction in the net capital inflows-to-output ratio.

In Column 4, a $1 \%$ increase in output per capita growth rate is associated with a $0.074 \%$ decrease in net capital inflows per output. In Column 7 , increasing output by $1 \%$ is associated with a $0.087 \%$ lower capital inflows-to-output ratio. In brief, with a higher productivity growth rate, net capital inflows decrease. 
Table 2. Fixed-Effects Estimation Results of Net Total Capital Inflows (negCA2y) and Their Decomposition (Savings (S2y) and Investment (I2y)) On Productivity Growth: 1980-2013

\begin{tabular}{|c|c|c|c|c|c|c|c|c|c|}
\hline VARIABLES & $\begin{array}{c}(1) \\
\text { negCA2y }\end{array}$ & $\begin{array}{c}(2) \\
\text { NS2y }\end{array}$ & $\begin{array}{l}(3) \\
\mathrm{I} 2 \mathrm{y}\end{array}$ & $\begin{array}{c}(4) \\
\text { negCA2y }\end{array}$ & $\begin{array}{c}(5) \\
\text { NS2y }\end{array}$ & $\begin{array}{l}(6) \\
\mathrm{I} 2 \mathrm{y}\end{array}$ & $\begin{array}{c}(7) \\
\text { negCA2y }\end{array}$ & $\begin{array}{c}(8) \\
\text { NS2y }\end{array}$ & $\begin{array}{l}(9) \\
\mathrm{I} 2 \mathrm{y}\end{array}$ \\
\hline $\begin{array}{l}\text { Productivity Growth } \\
\text { (TFPgrowth) }\end{array}$ & $\begin{array}{c}-0.226^{* * *} \\
(0.0359)\end{array}$ & $\begin{array}{c}0.340 * * * \\
(0.0396)\end{array}$ & $\begin{array}{c}0.0119 \\
(0.0207)\end{array}$ & & & & & & \\
\hline $\begin{array}{l}\text { Output-per-Capita Growth } \\
\text { (GDPpcgrowth) }\end{array}$ & & & & $\begin{array}{c}-0.0742 * * \\
(0.0296)\end{array}$ & $\begin{array}{l}0.350 * * * \\
(0.0323)\end{array}$ & $\begin{array}{l}0.170^{* * *} \\
(0.0184)\end{array}$ & & & \\
\hline $\begin{array}{l}\text { Output Growth } \\
\text { (GDPgrowth) }\end{array}$ & & & & & & & $\begin{array}{c}-0.0874 * * * \\
(0.0294)\end{array}$ & $\begin{array}{l}0.408 * * * \\
(0.0320)\end{array}$ & $\begin{array}{l}0.190 * * * \\
(0.0181)\end{array}$ \\
\hline Constant & $\begin{array}{l}4.912 * * * \\
(0.842)\end{array}$ & $\begin{array}{c}22.64 * * * \\
(0.950)\end{array}$ & $\begin{array}{l}27.29 * * * \\
(0.544)\end{array}$ & $\begin{array}{c}6.526^{* * * *} \\
(0.787)\end{array}$ & $\begin{array}{l}21.05 * * * \\
(0.872)\end{array}$ & $\begin{array}{c}26.51 * * * \\
(0.567)\end{array}$ & $\begin{array}{l}6.719 * * * \\
(0.792)\end{array}$ & $\begin{array}{l}20.14^{* * * *} \\
(0.871)\end{array}$ & $\begin{array}{c}26.09 * * * \\
(0.568)\end{array}$ \\
\hline Observations & 2,934 & 2,616 & 3,041 & 4,193 & 3,478 & 4,140 & 4,193 & 3,478 & 4,140 \\
\hline R-squared & 0.045 & 0.068 & 0.072 & 0.024 & 0.069 & 0.065 & 0.025 & 0.081 & 0.071 \\
\hline Number of ncode & 109 & 107 & 107 & 162 & 150 & 153 & 162 & 150 & 153 \\
\hline
\end{tabular}

(Note) Standard errors appear in parentheses. ${ }^{* *} p<0.01,{ }^{*} p<0.05,{ }^{*} p<0.1$. Net total capital inflows as a percentage (negCA2y) is the negative value of the current account divided by GDP. The savings-to-output ratio as a percentage ( $S 2 y)$ is gross savings divided by GDP. The investment-to-output ratio as a percentage $(I 2 y)$ is the gross capital formation divided by GDP. The productivity growth rate as a percentage (TFPgrowth) is the TFP growth rate. The output per capita growth rate as a percentage (GDPpcgrowth) is the growth rate of GDP per capita, which is GDP at constant national 2005 prices in USD divided by the total population. The output growth rate as a percentage (GDPgrowth) is the growth rate of GDP in constant national 2005 prices in USD. The

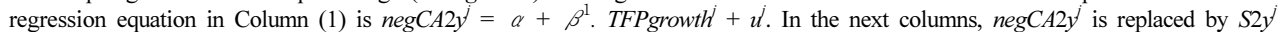
and $I 2 y^{j}$, while TFPgrowth is replaced by GDPpcgrowth ${ }^{j}$ and GDPgrowth. See the Framework section for more details.

The regression provides new evidence for a discussion of the pattern of international capital flows. The neoclassical growth model predicts that an economy with a higher productivity growth rate would receive more capital inflows. Recently, this implication has been supported with empirical evidence provided by Alfaro, Kalemli-Ozcan, and Volosovych (2014) using a cross-sectional sample of both emerging and advanced economies. In a cross-sectional sample of non-Organization of Economic Cooperation and Development (OECD) economies, however, Gourinchas and Jeanne (2013) discovered an allocation puzzle that when an economy is growing faster it tends to receive less net capital inflows. Our evidence shows that, on average across countries, an increase over time in the productivity growth rate reduces net capital inflows. Therefore, our regression results can be considered to be an extension of the allocation puzzle using a panel data sample.

Table 2 examines the channels through which the growth rate shapes the capital flow pattern. In Column 2, a $1 \%$ increase in the TFP growth rate is associated with a $0.34 \%$ higher ratio of savings to output. This increase can contribute to the $0.2 \%$ reduction in capital in Column 1 , since capital inflows equal investment minus savings. In Column 3 , the coefficient of the TFP growth rate is insignificant. Moreover, for two alternative measures of productivity growth, the regression shows that a higher growth rate exerts a negative effect on capital inflows by increasing savings more than investment. In Column 5, a $1 \%$ increase in per capita GDP growth is associated with a $0.35 \%$ higher savings rate, which is more than the $0.17 \%$ surge in investment in Column 6. In Column 7, the GDP growth rate increasing by $1 \%$ is associated with a $0.087 \%$ 
reduction of net capital inflows, which accounts for half of the difference between the $0.408 \%$ increase in savings in Column 8 and the $0.190 \%$ increase in investment in Column 9. The impact of productivity growth on net capital inflows is dependent on it having a greater effect on savings than on investment.

The regression of growth on savings and investment reveals that savings is an important channel through which the growth rate drives the pattern of capital flows. Indeed, an economy growing faster would result in it investing more and receiving more inflows of capital, as implied by the neoclassical growth model. The economy, however, also increases savings over time. Since the impact of growth on savings is stronger than its impact on investment, net capital inflows decrease the productivity growth rate. Therefore, the solution to the allocation puzzle regarding the pattern of capital flows needs to account for the impact of productivity growth on savings.

Table 3 investigates the role of the savings wedge in shaping the pattern of international capital flows. In Column 1, the savings wedge exerts a positive impact on the savings-to-output ratio. Specifically, a $1 \%$ increase in the wedge is associated with a $0.022 \%$ surge in the savingsto-output ratio. In Column 2, an increase in the savings wedge is associated with a reduction in net capital inflows. Indeed, if the wedge increases by $1 \%$, capital inflows shrink by $0.051 \%$, which is slightly higher than the increase in the savings rate induced by the wedge. In brief, the regression results reveal that the savings wedge negatively affects net capital inflows through its impact on the savings-to-output ratio.

Table 3. Fixed-Effects Estimation Results of Net Total Capital Inflows (negCA2y) and Savings (S2y) on the Savings Wedge: 1980-2013

\begin{tabular}{lcc}
\hline \multicolumn{1}{c}{ VARIABLES } & $(1)$ & $(2)$ \\
& S2y & negCA2y \\
\hline Saving Wedge (wedge) & $0.0217^{* *}$ & $-0.0505^{* * *}$ \\
& $(0.00843)$ & $(0.00966)$ \\
Constant & $20.23^{* * *}$ & $7.587^{* * *}$ \\
& $(0.937)$ & $(1.010)$ \\
Observations & 3,068 & 3,695 \\
R-squared & 0.045 & 0.030 \\
Number of ncode & 148 & 168 \\
\hline
\end{tabular}

(Note) Standard errors appear in parentheses. $* * * p<0.01, * * p<0.05, * p<0.1$. The net total capital inflows as a percentage (negCA2y) is the negative value of the current account divided by GDP. The savings-to-output ratio as a percentage $(S 2 y)$ is gross savings divided by GDP. The savings wedge as a percentage (wedge) is defined as the difference between the lending interest rate $\left(R^{l, j}\right)$ and the deposit interest rate $\left(R^{d, j}\right)$ for economy $j:$ Wedge $e^{j}=\left(R^{l, j}-R^{d, j}\right) / R^{l, j} * 100$. The regression equation in Column 1 is $S 2 y^{j}=\alpha+\beta^{2}$. Wedge $e^{j}+u^{j}$; and in Column 2 is negCA2 $y^{j}=\alpha+\beta^{2}$. Wedge $e^{j}+u^{j}$. See the Framework section for more details.

In the next step, given the impact of the savings wedge on net capital inflows, we will use the wedge as a potential candidate to explain the pattern of international capital inflows. 


\section{B. Intemational capital flows and the savings wedge}

Table 4 illustrates the results of regressing productivity growth on the savings wedge. In Column 1, the TFP growth rate has a positive impact on the wedge. A $1 \%$ increase in the TFP growth rate is associated with a $0.365 \%$ increase in the wedge. The same pattern applies for the alternative measures of growth, including per capita GDP growth in Column 2 and GDP growth in Column 3. Note that, in comparison with the magnitude of the impact on the savings wedge across three growth rates, the TFP growth rate has the greatest effect on the wedge. In brief, the savings wedge has an increasing impact on the productivity growth rate.

Table 4. Fixed-Effects Estimation Results of the Savings Wedge (Wedge) on Productivity Growth: 1980-2013

\begin{tabular}{lccc}
\hline \multicolumn{1}{c}{ VARIABLES } & $\begin{array}{c}(1) \\
\text { wedge }\end{array}$ & $\begin{array}{c}(2) \\
\text { wedge }\end{array}$ & $\begin{array}{c}(3) \\
\text { wedge }\end{array}$ \\
\hline Productivity Growth (TFPgrowth) & $0.365^{* * *}$ & & \\
Output-per-Capita Growth (GDPpcgrowth) & & $0.0744)$ & $(0.0455)$ \\
Output Growth (GDPgrowth) & & & $0.121^{* * *}$ \\
& & & $(0.0446)$ \\
Constant & $27.83^{* * *}$ & $30.32^{* * *}$ & $30.10^{* * *}$ \\
& $(1.845)$ & $(1.545)$ & $(1.550)$ \\
Observations & & & 3,452 \\
R-squared & 2,385 & 3,452 & 0.343 \\
Number of ncode & 0.382 & 0.343 & 152 \\
\hline
\end{tabular}

(Note) Standard errors appear in parentheses. ${ }^{* *} p<0.01, * * p<0.05, * p<0.1$. The savings wedge as a percentage (wedge) is defined as the difference between the lending interest rate $\left(R^{l, j}\right)$ and the deposit interest rate $\left(R^{d, j}\right)$ for economy $j$ : Wedge $e^{j}=\left(R^{l, j}-R^{d, j} / R^{l, j} * 100\right.$. The productivity growth rate as a percentage (TFPgrowth) is the TFP growth rate. The output per capita growth rate as a percentage (GDPpcgrowth) is the growth rate of per capita GDP, which is GDP at constant national 2005 prices in USD divided by the total population. The output growth rate as a percentage (GDPgrowth) is the GDP growth rate at constant national 2005 prices in USD. The regression equation in Column 1 is Wedge $^{j}=\alpha+\beta^{3}$. TFPgrowth $h^{j}+u^{j}$; in Column 2 is Wedge $=\alpha+\beta^{3}$. GDPpcgrowth $h^{j}+u^{j}$; in Column 3 is Wedge $e^{j}=\alpha+\beta^{3}$. GDPgrowth ${ }^{j}+u^{j}$. See the Framework section for more details.

In Table 5, we added the savings wedge and productivity growth together in the regression of net capital inflows and the savings-to-output ratio on productivity growth. In Column 1, adding the savings wedge caused the coefficient of TFP growth to become insignificant. Thus, as with the strategy employed by Alfaro, Kalemli-Ozcan, and Volosovych (2008), when the coefficient of the growth rate becomes insignificant, the evidence proves that the wedge can account for capital inflows' dependence on productivity growth. Moreover, controlling for the growth rates, a higher wedge is then associated with a reduction in net capital inflows. By accounting for the productivity growth rate, for a $1 \%$ increase in the savings wedge, capital 
inflows are decreased by about $0.05 \%$ in all columns. This evidence implies a similar pattern, as proven in Table 3, on the impact of the wedge on net capital inflows. In brief, the savings wedge functions as a crucial channel through which productivity growth exerts a negative impact on net capital inflows.

Table 5. Fixed-Effects Estimation Results of Net Total Capital Inflows (negCA2y) on the Savings Wedge and Productivity Growth: 1980-2013

\begin{tabular}{lccc}
\hline \multicolumn{1}{c}{ VARIABLES } & $(1)$ & $(2)$ & $(3)$ \\
& negCA2y & negCA2y & negCA2y \\
\hline Saving Wedge (wedge) & $-0.0498^{* * *}$ & $-0.0566^{* * *}$ & $-0.0566^{* * *}$ \\
& $(0.00896)$ & $(0.00977)$ & $(0.00978)$ \\
Productivity Growth (TFPgrowth) & 0.0313 & & \\
& $(0.0339)$ & & \\
Output-per-Capita Growth (GDPpcgrowth) & & $0.121^{* * *}$ & \\
& & $(0.0317)$ & $0.112^{* * *}$ \\
Output Growth (GDPgrowth) & & & $(0.0319)$ \\
& & & $7.662^{* * *}$ \\
Constant & $6.705^{* * *}$ & $7.856^{* * *}$ & $(0.906)$ \\
& $(0.832)$ & $(0.901)$ & 3,154 \\
Observations & & & 0.042 \\
R-squared & 2,218 & 3,154 & 151 \\
Number of ncode & 0.073 & 0.042 & 151 \\
\hline
\end{tabular}

(Note) Standard errors in parentheses. ${ }^{* * *} p<0.01,{ }^{* *} p<0.05,{ }^{*} p<0.1$. The net total capital inflows on percentage (negCA2y) is the negative value of current account divided by gross domestic product (GDP). The saving wedge on percentage (wedge) is defined as the difference between the lending interest rate $\left(R^{1, j}\right)$ and deposit interest rate $\left(R^{d, j}\right)$ for an economy $j$ : Wedge $=\left(R^{1, j}-R^{d, j}\right) / R^{1, j} * 100$. The productivity growth rate on percentage (TFPgrowth) is the growth rate of total factor productivity (TFP). The output per capita growth rate on percentage (GDPpcgrowth) is the growth rate of GDP per capita, which is GDP at constant national 2005 prices on USD divided by total population. The output growth rate on percentage (GDPgrowth) is the growth rate of GDP at constant national 2005 prices on USD. The regression equation on Column (1) is: negCA2 $y_{t}^{j}=\alpha+\beta^{\text {wedge }}$. W edge ${ }_{t}+\beta^{\text {growth }}$. T F P growth ${ }_{\mathrm{t}}^{\mathrm{j}}+\mathrm{u}_{\mathrm{t}}^{\mathrm{j}}$. On the next columns, (T F P growth) is replaced by (GDP pcgrowth) and (GDP growth). See section on Framework for more details.

Next, we performed a robustness check on the empirical model to glean more evidence on the role of the savings wedge.

\section{Robustness checks}

Table 6 shows the regression results of net capital inflows per capita on the independent variables. Dividing net capital inflows by the total population is a way to rule out the effect of country size on measuring capital flows. First, net capital inflows decrease with the growth rate for all three alternative measures of growth-TFP growth (Column 1), GDPpc growth (Column 3), and GDP growth (Column 5). The evidence confirms the existence of an extended allocation 
puzzle in the panel data sample, which is recorded in Table 2. Second, the savings wedge can account for capital flows' dependence on productivity growth. Indeed, the addition of a savings wedge makes the coefficient of growth insignificant for two measures of the growth rate: GDPpc growth (Column 4) and GDP growth (Column 6). In brief, for the various measures of net capital inflows, the evidence confirms the role of the savings wedge being a key driver of the pattern of international capital flows.

Table 6. Fixed-Effect Estimation Results of Net Total Capital Inflows Per Capita (negCApc) on the Savings Wedge and Productivity Growth: 1980-2013

\begin{tabular}{|c|c|c|c|c|c|c|}
\hline VARIABLES & $\begin{array}{c}(1) \\
\text { negCApc }\end{array}$ & $\begin{array}{c}(2) \\
\text { negCApc }\end{array}$ & $\begin{array}{c}(3) \\
\text { negCApc }\end{array}$ & $\begin{array}{c}(4) \\
\text { negCApc }\end{array}$ & $\begin{array}{c}(5) \\
\text { negCApc }\end{array}$ & $\begin{array}{c}(6) \\
\text { negCApc }\end{array}$ \\
\hline Saving Wedge (wedge) & & $\begin{array}{l}-2.392 \\
(1.549)\end{array}$ & & $\begin{array}{c}-3.434 * * * \\
(1.181)\end{array}$ & & $\begin{array}{c}-3.380 * * * \\
(1.181)\end{array}$ \\
\hline Productivity Growth (TFPgrowth) & $\begin{array}{c}-22.97 * * * \\
(5.151)\end{array}$ & $\begin{array}{c}1.285 \\
(6.080)\end{array}$ & & & & \\
\hline Output-per-Capita Growth (GDPpcgrowth) & & & $\begin{array}{c}-11.49 * * * \\
(3.415)\end{array}$ & $\begin{array}{c}3.220 \\
(3.988)\end{array}$ & & \\
\hline Output Growth (GDPgrowth) & & & & & $\begin{array}{c}-14.26^{* * *} \\
(3.337)\end{array}$ & $\begin{array}{c}0.447 \\
(3.922)\end{array}$ \\
\hline Constant & $\begin{array}{l}-175.9 \\
(121.1)\end{array}$ & $\begin{array}{c}57.73 \\
(143.4)\end{array}$ & $\begin{array}{l}-78.02 \\
(89.31)\end{array}$ & $\begin{array}{c}114.1 \\
(108.9)\end{array}$ & $\begin{array}{l}-46.66 \\
(89.74)\end{array}$ & $\begin{array}{c}115.3 \\
(109.3)\end{array}$ \\
\hline Observations & 2,959 & 2,228 & 4,237 & 3,171 & 4,237 & 3,171 \\
\hline R-squared & 0.031 & 0.050 & 0.016 & 0.025 & 0.018 & 0.025 \\
\hline Number of ncode & 109 & 103 & 162 & 151 & 162 & 151 \\
\hline
\end{tabular}

(Note) Standard errors in parentheses. ${ }^{* * *} p<0.01,{ }^{*} p<0.05,{ }^{*} p<0.1$. The net total capital inflows per capita on USD (negCApc) is the negative value of current account on current national prices on USD, divided by total population. The saving wedge on percentage (wedge) is defined as the difference between the lending interest rate $\left(\mathrm{R}^{\mathrm{l}, \mathrm{j}}\right)$ and deposit interest rate $\left(\mathrm{R}^{\mathrm{d}, \mathrm{j}}\right)$ for an economy $\mathrm{j}$ : Wedge $\mathrm{j}^{\mathrm{j}}=\left(\mathrm{R}^{1, \mathrm{j}}-\mathrm{R}^{\mathrm{d}, \mathrm{j}}\right) / \mathrm{R}^{1, \mathrm{j}} * 100$. The productivity growth rate on percentage (TFPgrowth) is the growth rate of total factor productivity (TFP). The output per capita growth rate on percentage (GDPpcgrowth) is the growth rate of GDP per capita, which is GDP at constant national 2005 prices on USD divided by total population. The output growth rate on percentage (GDP growth) is the growth rate of GDP at constant national 2005 prices on USD. The regression equation on Column (1) is: $\operatorname{negCApc}_{t}{ }_{t}=\alpha+\beta^{1}$. TFP growth ${ }_{t}^{j}+u_{t}^{j}$; on Column (2) is: negCApc ${ }_{t}^{j}=\alpha+\beta^{\text {wedge }^{j}}$. Wedge ${ }_{t}+\beta^{\text {growth }}$. TFP growth ${ }_{t}^{j}+u_{t}^{j}$. On the next columns, (TFPgrowth) is replaced by (GDPpcgrowth) and (GDPgrowth). See section on Framework for more details.

Table 7 reports the regression results of net capital inflows on the growth and savings wedges for a sample of non-OECD economies. The idea was to investigate emerging economies, which are at the foundation of most literature on cross-border capital flows, as motivated by Lucas (1990) and Gourinchas and Jeanne (2013). First, the negative impact of growth on capital inflows (in Table 3) is confirmed for all three measures of growth-TFP growth (Column 1), GDPpc growth (Column 3), and GDP growth (Column 5). Second, adding the savings wedge makes the coefficient of TFP growth on capital inflows (Column 2) become insignificant. For the 
two other measures of growth, the savings wedge still has a negative impact on net capital inflows as seen in the other two columns. In brief, for non-OECD economies, the savings wedge continues to play an important role in shaping net capital inflows' dependence on productivity growth.

Table 7. Fixed-Effects Estimation Results of Net Total Capital Inflows (negCA2y) on the Savings Wedge and Productivity Growth: Non-Oecd Economies, 1980-2013

\begin{tabular}{lcccccc}
\hline \multicolumn{1}{c}{ VARIABLES } & $(1)$ & $(2)$ & $(3)$ & $(4)$ & $(5)$ & $(6)$ \\
& negCA2y & negCA2y & negCA2y & negCA2y & $\begin{array}{c}\text { negCA2y } \\
\text { negCA2y }\end{array}$ \\
\hline Saving Wedge (wedge) & & $-0.0731^{* * *}$ & & $-0.0721^{* * *}$ & & $-0.0720^{* * *}$ \\
& & $(0.0119)$ & & $(0.0120)$ & & $(0.0120)$ \\
Productivity Growth (TFPgrowth) & $-0.217^{* * *}$ & 0.0504 & & & & \\
& $(0.0409)$ & $(0.0379)$ & & & & \\
Output-per-Capita Growth (GDPpcgrowth) & & & $-0.0723^{* *}$ & $0.124^{* * *}$ & & \\
& & & $(0.0325)$ & $(0.0345)$ & & \\
Output Growth (GDPgrowth) & & & & & $-0.0865^{* * *}$ & $0.116^{* * * *}$ \\
& $5.695^{* * *}$ & $8.436^{* * *}$ & $7.264^{* * *}$ & $9.049^{* * *}$ & $7.483^{* * *}$ & $8.817^{* * *}$ \\
Constant & $(1.086)$ & $(1.125)$ & $(0.938)$ & $(1.118)$ & $(0.944)$ & $(1.123)$ \\
& & & & & & \\
Observations & 2,274 & 1,748 & 3,533 & 2,684 & 3,533 & 2,684 \\
R-squared & 0.048 & 0.079 & 0.026 & 0.046 & 0.027 & 0.046 \\
Number of ncode & 87 & 82 & 140 & 130 & 140 & 130 \\
\hline
\end{tabular}

(Note) Standard errors in parentheses.***p $<0.01,{ }^{* *} p<0.05,{ }^{*} p<0.1$. The net total capital inflows on percentage (negCA2y) is the negative value of current account divided by gross domestic product (GDP). The saving wedge on percentage (wedge) is defined as the difference between the lending interest rate $\left(R^{1, j}\right)$ and deposit interest rate $\left(\mathrm{R}^{\mathrm{d}, \mathrm{j}}\right)$ for an economy $\mathrm{j}$ : Wedge $\mathrm{j}^{\mathrm{j}}=\left(\mathrm{R}^{1, \mathrm{j}}-\mathrm{R}^{\mathrm{d,j}}\right) / \mathrm{R}^{1, \mathrm{j}} * 100$. The productivity growth rate on percentage (TFPgrowth) is the growth rate of total factor productivity (TFP). The output per capita growth rate on percentage (GDPpcgrowth) is the growth rate of GDP per capita, which is GDP at constant national 2005 prices on USD divided by total population. The output growth rate on percentage (GDPgrowth) is the growth rate of GDP at constant national 2005 prices on USD. The regression equation on Column (1) is: $\operatorname{negCA}_{2} \mathrm{y}_{\mathrm{t}}^{\mathrm{j}}=\alpha+\beta^{1}$. TFP $\operatorname{growth}_{\mathrm{t}}^{\mathrm{j}}+\mathrm{u}_{\mathrm{t}}^{\mathrm{j}}$; on Column (2) is: negCA2 $y_{t}^{j}=\alpha+\beta^{\text {wedge }}$. Wedge $e_{t}^{j}+\beta^{\text {growth. }}$. TFPgrowth ${ }_{t}^{j}+u_{t}^{j}$. On the next columns, (TFPgrowth) is replaced by (GDPpcgrowth) and (GDPgrowth). See section on Framework for more details.

\section{Conclusion}

On a panel sample of 162 economies over the 1980-2013 period, the empirical evidence confirms that the savings wedge, a type of financial friction, determines the pattern of international capital flows. A higher growth rate is associated with a greater savings wedge, and, in turn, greater savings. It is also associated with increased investment. When savings increases more than investment, the increase in growth is associated with reduced inflows of capital.

This paper addresses a controversy regarding the pattern of capital flows. Since the improvement in the productivity growth rate increases investment to attract greater net capital inflows, the 
evidence confirms the prediction by the neoclassical growth model. Moreover, a higher growth rate also increases savings which, in turn, tends to discourage net capital inflows. This confirms the existence of the allocation puzzle established by Gourinchas and Jeanne (2013).

A future research avenue would be to decompose net capital inflows into its constituent public and private capital inflows. Gourinchas and Jeanne (2013) demonstrated that public capital flows decrease while private capital flows increase with productivity growth. Their paper, however, employed the use of cross-sectional data and therefore only focused on comparisons between countries. Using a panel data sample might be a way to potentially capture the dynamics of the pattern of public and private capital flows.

\section{References}

Alfaro, L., Kalemli-Ozcan, S., \& Volosovych, V. (2008). Why doesn't capital flow from rich to poor countries? An empirical investigation. Review of Economics and Statistics, 90(2), 347-368.

Alfaro, L., Kalemli-Ozcan, S., \& Volosovych, V. (2014). Sovereigns, upstream capital flows, and global imbalances. Journal of the European Economic Association, 12(5), 1240-1284.

Bernanke, B. S. (2005). The global saving glut and the US current account deficit. Speech at the Sandridge Lecture, Virginia Association of Economics, Richmond, Virginia.

Carroll, C. D., Overland, J., \& Weil, D. N. (2000). Saving and growth with habit formation. American Economic Review, 90(3), 341-355.

Coeurdacier, N., Guibaud, S., \& Jin, K. (2015). Credit constraints and growth in a global economy. American Economic Review, 105(9), 2838-2881.

Gourinchas, P. O., \& Jeanne, O. (2013). Capital flows to developing countries: The allocation puzzle. The Review of Economic Studies, 80(4), 1484-1515.

Gourinchas, P. O., \& Rey, H. (2014). External adjustment, global imbalances, valuation effects. In G. Gopinath, E. Helpman, \& K. Rogoff (Eds.), Handbook of international economics (pp. 585-645). Elsevier.

Lucas, Jr., R. E. (1990). Why doesn't capital flow from rich to poor countries? American Economic Review, 80(2), 92-96.

Matsuyama, K. (2004). Financial market globalization, symmetry- breaking, and endogenous inequality of nations. Econometrica, 72(3), 853-884.

Mendoza, E. G., \& Terrones, M. E. (2012). An anatomy of credit booms and their demise (NBER Working Paper No. 18379). Retrieved from https://www.sas.upenn.edu/ egme/wp/w18379.pdf

Obstfeld, M., \& Rogoff, K. S. (1996). Foundations of international macroeconomics, 30. Cambridge, MA: The MIT Press.

Prasad, E. S., Rajan, R. G., \& Subramanian, A. (2007). Foreign capital and economic growth (NBER Working Paper No. 13619). Retrieved from https://www.nber.org/papers/w13619

Sandri, D. (2014). Growth and capital flows with risky entrepreneurship. American Economic Journal: 
518 Journal of Economic Integration Vol. 35, No. 3

Macroeconomics, 6(3), 102-123.

Solow, R. M. (1956). A contribution to the theory of economic growth. The Quarterly Journal of Economics, 70(1), 65-94.

Song, Z., Storesletten, K., \& Zilibotti, F. (2011). Growing like china. American Economic Review, 101(1), 196-233.

Swan, T. W. (1956). Economic growth and capital accumulation. Economic Record, 32(2), 334-361. 